UDC 614.4+140.8+37.01(207+477)

DOI: https://doi.org/10.26661/hst-2019-2-79-04

\title{
MYTHS, PSEUDOSCIENCES, SCIENCES \& ARTS IN THE XXI CENTURY: NOOPHILOSOPHICAL ANALYSIS
}

\author{
@ KORSAK, KOSTIANTYN \\ Kyiv Medical University (Ukraine, Kyiv) \\ E-mail: kvkorsak@gmail.com, ORCID iD: https://orcid.org/ 0000-0001-7715-9720 \\ Kyiv Medical University, Boryspilska St., 2, Kyiv, Ukraine, 02099, \\ @ KORSAK, YURII \\ Institute of Higher Education of NAPS of Ukraine (Ukraine, Kyiv) \\ E-mail: olte@ukr.net, ORCID iD: https://orcid.org/ 0000-0003-3100-8630 \\ Institute of Higher Education of NAPS of Ukraine, Bastionna St., 9, \\ Kyiv, Ukraine, 01014 \\ @ LYASHENKO, LARYSA \\ Taras Shevchenko National University of Kyiv (Ukraine, Kyiv) \\ E-mail: larnik1881@ gmail.com, ORCID iD: https://orcid.org/ 0000-0002-6860-8552 \\ Taras Shevchenko National University of Kyiv, Volodymyrska St. 60, \\ Kyiv, Ukraine, 01033 \\ @ POKHRESNYK, ANATOLII \\ Kyiv College of Electronic Devices (Ukraine, Kyiv) \\ E-mail: ktep2006@ukr.net, ORCID iD: https://orcid.org/0000-0002-4637-7140 \\ Kyiv College of Electronic Devices, Patris Lulumba St. 17, Kyiv, Ukraine, 01042
}

\begin{abstract}
Homo Sapiens Sapiens has increased its population by about 1 million times and conquered the planet. But it is still in danger and may die because it has become a major destructive element of the biosphere. It has become particularly evident with the outbreak of global CoViD-19 pandemic. The research is determined by professional ethics and desire to offer real means for dealing with pandemics and collapses. We see the goal in critical analysis of well-known future forecasts. Specific tasks are to propose real steps towards gradual construction of the noosphere bases. The methods of classical scientific achievements, critical, historical, logical and comparative analysis have been used. They are complemented by the achievements of nootechnology and noosciences required for strategic projections over a long period of time. We use an infographics to provide explanations and suggestions. The narrow scope and falsity of the well-known apocalyptic predictions of the future have been attested. The reasons for this manifestation and the lack of real projects for the elimination of the threat of new pandemics have been explained. It has been proved the fact of the staying of mankind at the next bifurcation point. Besides it is proposed to move into the noofuture with eco-friendly nootechnologies which must completely replace the industrial and smart ones. It has been proved the fact of the emerging of "noowave" in the evolution of mankind, which receives the impulse of growth from the conjunction of humanities and natural noosciences with nooprocesses. The elimination of a new pandemics threat is quite possible in the case of humanity's coordinated nooprogress plan along with the use of solar energy and high generation replicators (3D printers) on natural materials.
\end{abstract}

Keywords: humanity crisis, stages of evolution, myths, pseudosciences, Sciences $\&$ Arts, nootechnologies, noosciences

Myths, pseudosciences, sciences \& arts in the XXI century noophilosophical analysis 


\section{INTRODUCTION}

The arrival of 2020 will forever enter the history of mankind as the beginning of a new era in his life. The global electronic and print media have chosen the pandemic as their main topic and almost forgot about global warming. They even write little about world terrorism and the struggle of civilizations that $\mathrm{S}$. Huntington so accurately predicted [7]. His forecast is an exception from all known big predictions [5; 6], which in most cases proved to be erroneous due to the neglect of technological progress.

The authors are constantly communicating with contemporary students of the "Generation Z". We transfer not only professional knowledge, but also answer philosophical questions about civilizational values in the medical profession and trends in the evolution of all mankind. It forces us to follow new discoveries and achievements that give us facts to answer these questions. In this article, we briefly outline our thoughts on the evolution of mankind and provide a prognosis for the end of the XXI century.

The purpose of the article is critically analyze the widespread beliefs about the past of humanity and the main projections of the future in order to create more accurate vision for development after 2020. We have chosen to search for entirely new information in order to formulate a proposal of real and practical steps to the salvation of mankind. We will prove that the idea of smart society has significant disadvantages, and the use of the concepts nooscience and nootechnology can accelerate the construction of the noosphere, as a complex system of humanity and the restored and healed biosphere.

Most of the methods we use are well-known classical achievements of the exact sciences and humanities. But we complement this knowledge with the latest breakthroughs in many young scientific sectors that we propose to call "nooscience." From our own experience, we have been convinced that students have a positive appreciation of the use of infographics achievements in our lectures. Young people respect the laws of Nature and are ready to cooperate with teachers who offer effective ways for building professional competence and high civilization morale.

The results obtained are to identify the shortcomings of widespread wellknown apocalyptic predictions for the future, to prove the fallacy of those that most appeal to the owners of modern media and fill not only the mass media, but also the Internet. We offer an alternative to these dangerous views together with a project to eliminate the conditions for pandemics and environmental collapse.

\section{CRITICAL ANALYSIS OF MATERIALS ON THE TOPIC "HUMANITY AND PROGRESS"}

There is a great deal of electronic and printed material on the state of modern mankind and predictions for further evolution. We have focused our research not on creating an analytical overview of this information, but on finding the latest 
discoveries that force us to refine our visions of past events and phenomena, together with the creation of a reliable forecast base for the long term.

The advent of the information and technological revolution has led to the emergence of a large stream of scientific papers on possible changes in society, economy and culture. The authors of most articles in Ukraine and in the world have chosen to reproduce the text of Manuel Castells, in particular, his great three volume work [4]. They copied both the terminology and the style of presentation of this Spanish sociologist who became a worldwide celebrity through media efforts.

We do not support such high grade and do not recommend students and postgraduate students to study this and other books by M. Castells in the first place. Our views are based on the study of the greatest books that influenced the world in the last third of the twentieth century. We consider the best two great books by Harvard professor D. Bell $[1 ; 2]$ and the Soviet scientist V.I. Rakitov [26]. Of these three, only Bell's first book had a happy fortune and was widely distributed in many translations. His second book was ignored by The West for "excessive" veracity. The book by V.I. Rakitov, which contains a beautiful generalization of humanity and correct predictions of ICT development, emerged at the moment of the collapse of the USSR and remains little known today.

The famous modern Russian scientist V.L. Inozemtsev gave an objective assessment of the aforementioned book by M. Castells and about 40 influential books by scholars of the West [8]. He gave a detailed analysis of M. Castells work and noted that it contained wellknown event descriptions and statistics. There is no definition of an information society in the book, and conclusions and recommendations repeat the introductory pages and make up $2 \%$ of the volume of the book [8, p.16].

We have emphasized this fact with the desire to pay increased attention to readers to evaluate the usefulness of scientific works from different countries. Leadership in the value of the results obtained in the exact sciences belongs to authors from those Western countries who can spend fantastic resources to acquire and use the latest measuring and computer equipment. But the products of Western humanities do not deserve such praise. In the course of their studies, they have not yet learned the information from the exact sciences and cannot deeply assess the values and perspectives of the whole complex of modern knowledge. Their forecasts are unrealistic and even erroneous. The framework of the article does not allow us to supplement the M. Castells phenomenon by many other similar examples.

If we compare the information and prognostic value of various philosophical periodicals in postSoviet territories, we give priority not to the Moscow magazine "Problems of Philosophy", overly concerned with proving the spiritual superiority of Russians over other peoples, but to the "Humanities Bulletin of Zaporizhzhya 
State Engineering Academy" - ZSEABulletin

(URL: http://vestnikzgia.com.ua/issue/archiv e). The fate united together a small team of like-minded people, to which many creative authors from all over Ukraine and part of abroad gradually joined.

Careful reading of the easy-to-use archive of the ZSEA-Bulletin gives a good impression about the evolution of the subject matter of the articles and the expansion of their authors' outlook. We have decided to include only a small part of all publications in our article mainly English for 20192018 [3; 9; 14-25; 27-33; 35-37]. Previously, the authors of the articles have written mostly about environmental issues, the sustainable development project and the prospects of using computers in the educational process and in manufacturing. In the XXIst century the focus was on the information society in all its features and in the trends of higher education that have become relevant in Ukraine and in the world. Recently, the innovation has been the inclusion of smart society, STEM education and many other important innovations and trends into the analysis.

The theme of "sustainable development" remains important, so articles $[15 ; 23 ; 20 ; 35 ; 36]$ are devoted to it. They analyzed the main achievements of recent years and provided forecasts. We agree with the following generalization: "Artificial intelligence and other technologies can improve the economy, create new types of work and promote human capabilities. In recent years, the digital revolution has transformed our lives through breakthrough technological ideas, turning over a century-old business model of companies, and creating an economy where algorithms dominate, leading to largescale changes in work, business and economics. The conceptual model of a systematic analysis of a sustainable development economy at the time of digitalization is improved, which is based on studying problems and forecasting indicators of economy sustainability" [36, p.86]. But there are more articles with a detailed study of innovative and promising technologies and proposals for their effective application $[17 ; 22 ; 27 ; 28$; 30]. We note the quotation of $\mathrm{O}$. Sosnin's proposal from [28]: "The modern state should respond timely to the challenges of scientific and technological progress, adequately respond to the key issues of identifying the problems of information and communication activities in the context of modern globalization challenges" [28, p.169]; S. Sidorenko "The feature and fundamental difference of globalization 4.0 is the synthesis of new technologies and their interaction in physical, digital and biological domains" [30, p.44]

The concentration of the authors of the ZSEA-Bulletin on the problems of the present and the future explains a small number of articles on the history of philosophy (exception [16]) or with a presentation of the works of foreign scholars. Much more analysis of particularly complex theoretical questions [18; 31] and general outlook and fundamental paradigms for education and life [9; 
15; 25; 35]. Many scholars are attracted by the problem of education of modern youth in the aspects of resistance to harmful information influences $([24 ; 29]$, etc.). There are a number of articles with a high concentration on the topic of futurology ([14; 16], etc.).

Of all the references, we will isolate V. Tovarnichenko's article [33]. Most of the articles we have selected deal with the problem of the transition of the information society into a smart society, but only this article contains in the title the term "Smart-society". But the originality of V. Tovarnichenko is to emphasize the in-depth study of the phenomenon of dissemination of pseudoscientific research and publications, which he summarizes in the conclusions to the article. They are very important and we will present them without any reductions: "1. The main principle of postmodernism is the new for the sake of the new. And this principle is fundamentally influenced by the development of modern science. 2. In today's modern Smart Society, the amount of information is growing in arithmetic progression, textbooks are overloaded with mathematical calculations. 3. The Genesis of Science cannot be considered separately from events taking place in the cultural and political life of society. 4. It is convenient to declare the representatives of the competing paradigm pseudoscientific and the paradigm itself pseudoscientific. 5 . Pseudoscience is a specific type of research and a form of ideology. 6 . Pseudoscience arises in the period of rapid development of science. This applies especially to those areas of natural science based on the unification of ideas and methods of the various sciences. 7. Signs of pseudoscience can be defined as follows: the idea is the way forward, the devoid of theoretical and experimental arguments, which is in isolation from the logic of the development of science. At the same time, in this idea there is a big claimpseudo-scientist undertakes "world" problems and promotes to revolutionize both science and practice" [33, p.24].

In our text, we look at "world problems" and make proposals to eliminate pandemics and collapses for all humanity. Our readers can decide whether this article belongs to the field of pseudoscience.

\section{OUTLINE OF THE MAIN RESULTS}

We invite readers to solve the problems of the future with us on the basis of a small use of facts from the history of the evolution of mankind and the sciences and a considerable concentration on terms and concepts "from the future." Without these words it is impossible to describe the events of the middle of the XXIst century just as in the 1950s the current situation-XXI could not be explained without the terms "computer," "network," or "Internet." All these new words contain at the beginning three letters "noo", which emphasize their fundamental difference from the more traditional and well-known that we will not specify. Among our new concepts are the terms "nootechnology" and "nooscience". 
The dividing line between nootechnology and all other known variants (alchemical, industrial, smart technologies, etc.) is that nootechnology is environmentally friendly and does not damage the biosphere. They are able to provide people with everything they need and even treat the modern, very diseased biosphere. All smart technologies known to us from the media and scientific articles are environmentally harmful, differentiating from the classic industrial by less harmful emissions and higher suitability for recycling old and unwanted products.

The first author in the 1990s was particularly interested in ecology, writing textbooks and articles, and focused on seeking the way to eliminate the threat of environmental collapse. At the time of the coming of the new century, he noticed in the large stream of nanotechnologies two unique - completely harmless to the environment. Attempts to disseminate this information in the scientific world have proved fruitless. Only in 2010, when there were four ideal technologies, they got a successful name - wisdom technology or nootechnology. Here is information about the first four nootechnologies:

«1) Creation of biological waste using specific bacteria plastics with normal mechanical properties, which self-decompose quickly in the environment;

2) Transformation with the use of cheap photocatalytic compounds of normal light absorption into effective bio-decontamination of body surfaces and air on the premises;

3) Formation of display and other organic films by controlling changes in viruses and similar nanostructures;

4) Converting sand cover by using the activity of bacteria into a solid sandstone, applicable in construction "[10, p.22].

There are now more than 225 nootherms and they are included in the legitimized Nooglossary [11].

We refer term "noophilosophy" to an advanced version of classical philosophy, which in all aspects uses the latest discoveries of a very large group of young sciences and research sectors covered by the concept of "nooscience". Noophilosophy combines the sciences and the humanities (Sciences \& Arts). The correct and synergistic combination of these equal parts makes it possible to obtain qualitative arguments and conclusions. In the future, for readers from Ukraine and parts of other countries where Soviet terminology is stored, the word "science" will refer to the complex "Sciences \& Arts". We will make adjustments if necessary.

Further presentation of the results will be shorter and easier to read when using infographics rather than long texts. We offer the author's Figure 1 with an outlined scheme of evolution of humanity, sciences and technologies. 
Wave-evolution of Homo Sapiens Sapiens

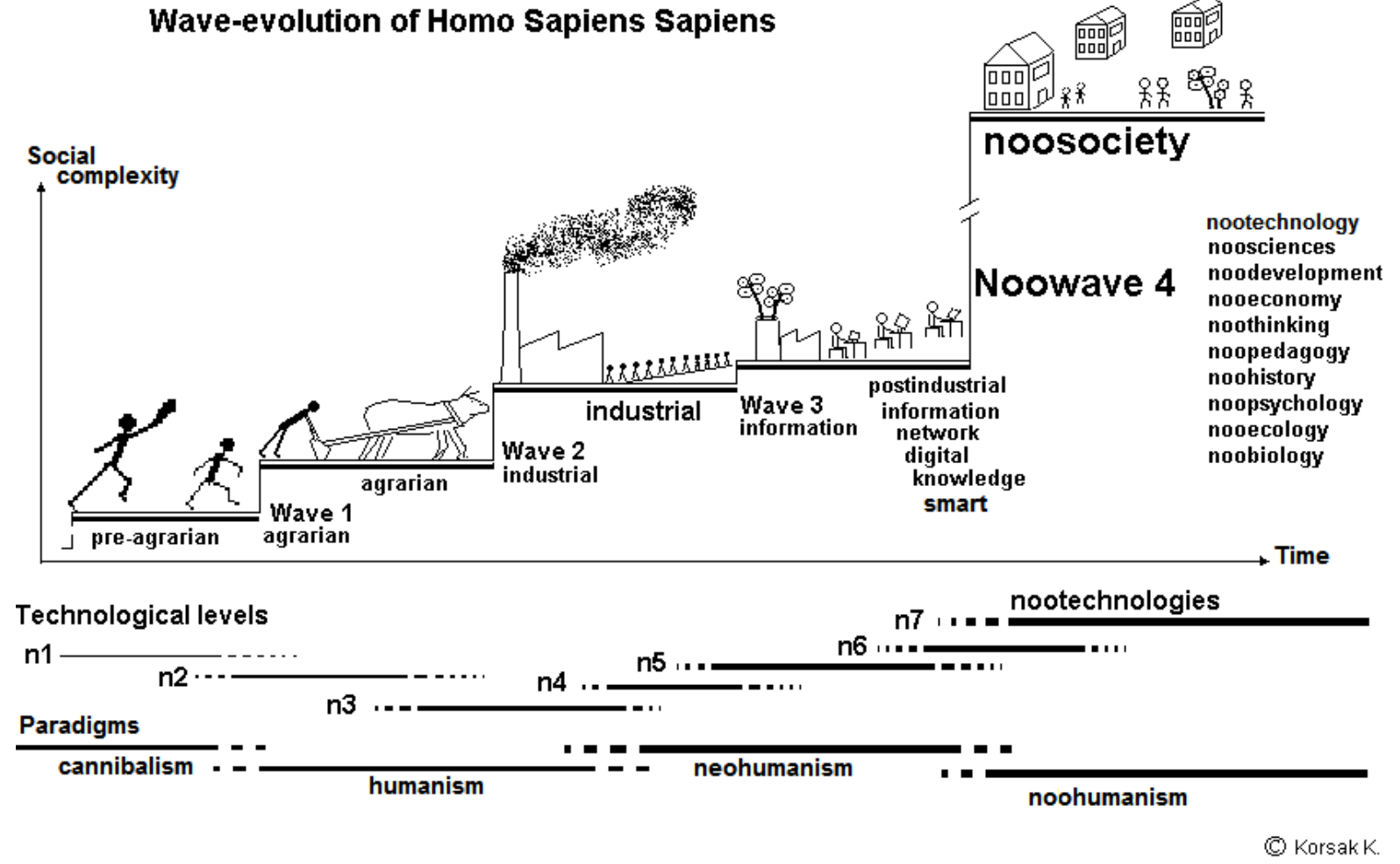

Fig. 1. The scheme of human evolution: the development of technology, the complexity of the structure and paradigm changes in life

The primitive variant of this scheme was created by us to explain the students the idea of the American sociologist E. Toffler (1928-2016) about the movement of Homo Sapiens on the three steps of progress from the hunter-gatherer society of cannibals to the post-industrial information society [32]. E. Toffler appreciated the "third wave" very much and considered it the largest and most important. Most scientists supported him and suggested many terms for his consequences as indicated in Fig. 1. Practically all given names of the new society emphasized the achievements of scientists and engineers in the creation, accumulation, dissemination and use of e-information.

We have supplemented the scheme with the much more important "4th" wave of nootechnology and nooscience. Its height is much higher than in the previous ones.

The horizontal axis indicates the change of time only qualitatively, but also it is enough for reproduction of changes of technological levels from the 1st (very primitive), to the 7th future nootechnologies. Below is a change in the outlook and paradigm of human activity - from very ancient cannibalism to modern neohumanism and the future of noohumanism.

The vertical axis gives a very rough idea of the changes in the complexity of societies and the growth of social interactions. We borrowed the term "Social complexity" from a group of scientists from the United States and other countries who have organized the international scientific research project "Seshat" for a joint computer 
study of the evolution of societies and changes in their characteristics. The database they created contains information on over 400 different variants of civilizations over a period of 10,000 years. For their differentiation, they use not only dates, but also many demographic, cultural and other indicators. Among them is the concept of "social complexity". 30 examples of societies with different social complexities were selected for computer analysis and comparison.

The main drawback of Seshat theories and the database mentioned is disregard the concept of "peneplain civilization" for peoples living on the site of very eroded mountains. On peneplain territory it is more difficult to organize agricultural activity, but they provide many opportunities for technological inventions, metallurgy, blacksmithing and efficient transportation. Since 2000, archeometry and paleogenomics, along with isotope physics and genetics, have made many discoveries ([12] and others) that have provided accurate explanations for the emergence of Indo-European culture and the large family of related languages.

Developing the provisions of $\mathrm{V}$. Tovarnichenko's article on pseudoscience in our time and in the future [33], we will briefly outline the main aspects of the changes in the time of the complex of myths, primitive sciences and Science \& Arts.

Modern cognitive science and other such nooscientific discoveries reveal the secrets of human thinking and the laws of its nervous system. It turned out that for peace of mind, a person needs to find explanations for the phenomena and processes he encounters in his environment. In the ancient past, these explanations were quite persistent myths that have been retained by broadcasters for a long time in this nation. The practice of working with natural materials formed the knowledge of the "exact" sciences of that time - materials science, mechanics, hydraulics, etc.

The main zone of discoveries was the peneplain arc: Eden - Anatolia Eastern Bulgaria - Ukraine (Trypillya) - Great Trypillya as an economic zone between the Carpathians and the Altai with a center in the Southern Urals. Here arose a common vocabulary of the Indo-European language family, which spread from the Atlantic to the deserts of China through the mechanism of the spread of important terms - "tag cloud" ([13] and others). The alluvial civilizations of the Nile Delta and Mesopotamia derive their agrarian and other technologies from Eden, where the first model of the Ring Observatory (or Stonehenge) was invented and erected by the ancestors of Ukrainians and other European peoples 13,500 years ago.

The time of success of Ancient Greece came 8-10 centuries after the collapse of the Great Trypillya as a result of the spectacular explosion (3600 years ago) of the Santorini volcano in the Aegean Sea. This period is known as the era of the disappearance of many "southern empires." The technological and spiritual impact of a number of newcomers from Trypillya has led to 
the rapid development of the southern Balkans and the many diverse achievements of the male part of Greece. The Greeks invented a multitude of Gods and instructed each of them to command a sector. The Gods were not perfect and often behaved badly - as humans. What is very important to us is the indisputable fact that a coherent system of spiritual views has formed around the Aegean Sea - a rather perfect version of what we call "classical philosophy".

While the first part of the Sciences \& Arts complex has been continuously evolving for thousands of years and has now accelerated its progress, the second, in our opinion, was formed in such a perfect way in a relatively short time that it later underwent minor improvements at certain moments of paradigm shifts under the pressure of technological progress.

We consider the stellar time of classical philosophy in the nineteenth century and the activities of the Berlin Research University. At that time, there were so few institutions and scientific journals that virtually every philosopher or other scholar could follow the vast majority of discoveries and easily make their own. It is expedient to mention not only the creator of this ideal for his time University of V. Humboldt (17671835), and his brother Alexander (1769-1859). A. Humbold created the colossal five-volume encyclopedia Cosmos, which he presented to us, outlining almost all scientific knowledge at the time of the end of the first half of the XIX century. He proposed

the

concept

"intellectosphere". Intellectosphere was transformed in the XX century into the word noosphere. Philosophy in the XIX century was the queen of the whole complex "Sciences \& Arts", but with the development of events in the XX century it lost its influence and became a fruitless "postmodernism" ([16] and others)

It is known that at the time of the end of the Second World War, the Sciences became the total dictator of fashions in the noosphere of the time, which did not benefit either nuclear physics or other exact sciences or the entire world of knowledge. Fortunately, humankind has failed to conduct a World War III nuclear missile test. The disappearance of the USSR and the camp of its satellites has shifted the priorities in the Sciences from rocket-space competitions to the deployment of a sea of human research, the work of the brain, nervous and all other systems of our body. At the moment, the Sciences \& Arts complex is developing relatively well and successfully, so we are sure of its new successes.

Let us end this snippet of the analysis of the history of Sciences \& Arts in recent times, with a reminder that there has always been a lack of people who sought to glorify and influence other people not only by inventing a new religion or creating another sect, but also by offering the views that so well defined and described as "pseudoscience" by V. Tovarnichenko [33]. We consider moderately harmful the doctrine of the spiritual and energetic nature of all 
available and the theory of domination of torsion fields is almost outside the Universe. But the pseudoscientific proposal of K. Marx and F. Engels to realize the movement to earthly paradise by granting total power to the social margins led to enormous human losses in the Russian Empire and in the unfortunate Kampuchea.

We actively explain to students the danger of lying offered to the general public in the form of "scientific discoveries" in the hope of earning financial profits or political dividends. To save space, let's limit ourselves to a simple author's list of six similar anti-scientific achievements of the last decades. Participants are - media and authors of lies: 1) Anticholesterol "pseudomedicament" (statins), which are needed not by everyone, but by a mini-percent of sick persons. 2) Antinarcotic and antidepressant "pseudomedicament" (oxycontin, etc.) of companies of the Sackler family in the United States. 3). Establishment of a Climate Committee at the UN and the invention of a dangerous lie about the dire threat of rapid "global warming". 4). The use of the Dupont phenomenon of the natural "ozone hole" over Antarctica to initiate the replacement of cheap and safe freons with much worse compounds. 5). Inventing the theory of "one-handed cancer" in the United States by inhaling asbestos dust and replacing this wonderful natural material with worse artificial ones (in Ukraine, this project failed only because of our extreme poverty). 6). Inventing the idea of the need for social support for people with mental and gender abnormalities and giving them significant social advantages over all normal people.

We would like to propose simply to ban the media, but the Internet remains, which at the moment has created an ideal environment for pseudosciences, anti-science and outright lies. And unfortunately nobody knows how long we will have to wait for the transformation of Artificial Intelligence into a serious prosecutor and defender of the truth.

\section{CONCLUSIONS AND SUGGESTIONS}

Our main innovation is the additional wave on the right side of Fig. 1 - Noowave. The tangible technologies in the nearest noodevelopment will provide mankind with entirely new production capabilities, among which we will only highlight those that permanently eliminate the possibility of the emergence and spread of dangerous pandemics throughout the planet.

The idea of the threat elimination is almost obvious: it is enough to stop completely contacts between people, ensuring their isolation in as little territory as possible at the hot point of the epidemic. At now it is impossible.

Therefore, the main perspective and immediate goal of the sciences is to control the flow of sunlight. In this topic, we prefer perovskite $\left(\mathrm{CaTiO}_{3}\right)$ nanofilms, though other options are also possible. The more problems have the scientists who created a cheap family battery that can provide people with electricity not only during the night, but for a long period of time. And this problem will be solved 
soon, either sodium-based or in another way.

Family isolation implies that a sufficiently powerful family-owned solar power plant will provide electricity to modern devices that capture water from the air and clean existing fluid at the family's place of life. To get food, it is necessary to create and use a very sophisticated version of modern 3D printers (they should be called "replicators") that can convert almost any organics into food. The most things will be made of nanocellulose and common natural substances (like sand and clay).

Creating such sets for family selfisolation for a necessary period of time is a serious challenge for modern scientists and engineers. If the above problems are overcome, it will cost \$ 50,000 in 2025.

This analysis of the flow of new advances in nootechnology lead to the "Technological paradise" in 20-30 years. These assets are indeed capable of not only protecting mankind from pandemics and ecological collapse. We will have an opportunity to combine the gradual population increase with the "cure" of the biosphere and the improvement of quality and life safety systems.

Unfortunately, there can be some kind of obstacles - defects in behaviour and thinking of the vast majority of mankind.

But their detailed analysis and suggestions of victory over them is a topic for another article.

\section{Список використаних джерел}

1. Bell, D., 1973. The Coming of Post-Industrial Society. A Venture in Social Forecasting, NewYork: Basic Books.

2. Bell, D., 1976. The Cultural Contradictions of Capitalism, NewYork: Basic Book.

3. Bojko, E., Voronkova, V., Nikitenko, V., 2018. Methodology and organization of scientific researches in the field of social-humanitarian and behavioural sciences. Humanities bulletin of Zaporizhzhe state engineering academy. 72. 23-35.

4. Castells, M. The Rise of the Network Society, The Information Age: Economy, Society and Culture, Vol. I. (1996); Vol. II. (1997); Vol. III. (1998). Cambridge, MA; Oxford, UK.

5. Ernst Ulrich, von Weizsacker, Anders, Wijkman, 2018. Come On! Capitalism, Shorttermism, Population and the Destruction of the Planet. A Report to the Club of Rome. Springer.

6. Gaudin, T., 1990. 2100 recit du prochain siecle. Paris: Editions Payot.

7. Huntington, S., 1996. The Clash of Civilizations and Remaking of World Order. Simon $\&$ Schuster.

8. Иноземцев, В. Л., 2005. Книгочей. М.: Ладомир, 2005. 464.

9. Kirik, T. V., Shevchuk, I. K., Kirik, V .O., 2018. Competition of humanist paradigms during the reform of higher education in Ukraine. Humanities bulletin of Zaporizhzhe state engineering academy. 75. 119-131

DOI: https://doi.org/10.30839/2072-7941.2018.155558.

10. Корсак, К. В., 2011. Нооекономіка (4-та хвиля) - шлях сталого розвитку людства у XXI столітті. Економіст. 2011. 1. 20-23

11. Корсак, К. В., Корсак, Ю. К., 2019. Свідоцтво про реєстрацію авторського права на літературний письмовий твір наукового характеру «Nooglossary-2 - Noosciences for the Future without Collapse» («Nooglossary-2»). №89780. 13. 06. 2019 р. К.: Міністерство економічного розвитку і торгівлі Украӥни, Департамент інтелектуальної власності.

Myths, pseudosciences, sciences \& arts in the XXI century noophilosophical analysis 
12. Корсак, К. В., Корсак, Ю. К., 2017. Нооісторія і ноонауки про можливість другого українського одуховлення світу. Гуманітарний вісник Запорізької державної інженерної академї: Збірник наукових пращь. Запоріжжя : ЗДІА. 69. 112-119.

13. Корсак, К. В., Ляшенко, Л. Н., 2017. Гипотеза феномена происхождения и распространения на планете индоевропейской семьи языков. РЭЛГА. №3 [321] 15.03

(URL: http://www.relga.ru/Environ/WebObjects/tguwww.woa/wa/Main?textid=4921\&level1 $=$ main\&level2=articles

14. Korsak, K. V., Korsak, Y. K., 2018. The only way to save humanity from total collapse - nootechnologies and noosciences. Humanities bulletin of Zaporizhzhe state engineering academy. 74. 24-38

DOI: https://doi.org/10.30839/2072-7941.2018.149632.

15. Kozlovets, M. A., Horokhova, L. V., Melnychuk, V. V., 2019. Humanistic type of rationality as a factor of the formation of co-evolution-innovation strategy for sustainable development of mankind. Humanities bulletin of Zaporizhzhe state engineering academy. 77. 47-68

Doi: https://doi.org/10.30839/2072-7941.2019.177708.

16. Kyrychenko, M., 2018. Concept of simulacra of virtual-online culture of informational society: conceptual survey of postemodernists. Humanities bulletin of Zaporizhzhe state engineering academy. 73. 62-71.

17. Kyurchev, V., Oleksenko, R., 2019. Creative personality and its dignicular role in the formation of a known economy in the conditions of the challenges of globalization of informational society. Humanities bulletin of Zaporizhzhe state engineering academy. 76. $132-145$

DOI: https://doi.org/10.30839/2072-7941.2019.165111

18. Levcheniuk, Y., 2018. From human to posthuman. Humanities bulletin of Zaporizhzhe state engineering academy. 72. 62-70.

19. Melnik, V., 2018. A new strategy of education as factor of sustainable development in the conditions of evolution from informational society to "Society knowledge". Humanities bulletin of Zaporizhzhe state engineering academy. 73. 146-156.

20. Melnyk, V. V., 2018a. Sustainable development management concept in fourth wave of globalization (globalization 4.0). Humanities bulletin of Zaporizhzhe state engineering academy. 75. 180-192

DOI https://doi.org/10.30839/2072-7941.2018.155563.

21. Melnyk, V. V., 2018. Information management as a factor of innovative society development. Humanities bulletin of Zaporizhzhe state engineering academy. 74. 3947

DOI: https://doi.org/10.30839/2072-7941.2018.149651).

22. Melnyk, V. V, 2019. Formation of the developmental concept of informativedigital technologies in digital (electronic) conditions of the era. Humanities bulletin of Zaporizhzhe state engineering academy. 76. 200-209

DOI: https://doi.org/10.30839/2072-7941.2019.165135

23. Nikitenko, V. O., 2018. Human interaction, culture and education as a key driver of sustainable development information. Humanities bulletin of Zaporizhzhe state engineering academy. 75. 79-89

DOI https://doi.org/10.30839/2072-7941.2018.155555

23. Nikitenko, V., 2018. Formation of "clip culture" and its impact on development and self-identification of personality in informational society. Humanities bulletin of Zaporizhzhe state engineering academy. 73. 105-113.

24. Punchenko, O., Voronkova, V., Vodop'yanov, P., 2019. "New Enlichtenment": new fractality in transformation processes of education. Humanities bulletin of Zaporizhzhe state engineering academy. 77. 144-159

DOI: https://doi.org/10.30839/2072-7941.2019.177746

(C) Korsak Kostiantyn, Korsak Yurii, Lyashenko Larysa, Pokhresnyk Anatolii 2019 
26. Ракитов, А. И. Философия компьютерной революции. М.: Политиздат, 1991. 287.

27. Rizhova, I., Shmarina, A., 2019. The impact of innovative technologies on a design of the spatial - object environment as a factor of gradual development. Humanities bulletin of Zaporizhzhe state engineering academy. 76. 90-102

DOI: https://doi.org/10.30839/2072-7941.2019.165097.

28. Sosnin, A., 2019. New approaches to the analysis of information and communication activities in the conditions of modern globalization challenges. Humanities bulletin of Zaporizhzhe state engineering academy. 76. 169-183

DOI: https://doi.org/10.30839/2072-7941.2019.165126.

29. Sosnin, O. V., Kononets, M. O., 2019. Problem issues of education of youth information and communication sustainability in the conditions of the new psycho-computer reality. Humanities Studies. 1 (78). 62-74

DOI https://doi.org/10.26661/hst-2019-1-78-05

30. Sydorenko S., 2019. Philosophy of digital technology development in the sphere of medicine in "globalization 4.0". Humanities bulletin of Zaporizhzhe state engineering academy. 76. 44-55

DOI: https://doi.org/10.30839/2072-7941.2019.165084

31.Teslenko, T. V., 2018. «Spirit/mind-body» dihotomy and its impact on the formation of «homo creativus» in the context of economic philosophy: methodological bases. Humanities bulletin of Zaporizhzhe state engineering academy. 75. 53-64

DOI https://doi.org/10.30839/2072-7941.2018.155552

32. Toffler, A., 1980. The Third Wave. New York: William Morrow.

33. Tovarnichenko, V., 2019. Pseudoscience and information security in smartsociety. Humanities Studies. 1(78). 15-26.

DOI https://doi.org/10.26661/hst-2019-1-78-01

34. Turchin, P., Brennan, R., Currie, T., Feeney, K., François, P., Hoyer, D., Manning, J., Marciniak, A., Mullins, D., Palmisano, A., Peregrinej, P., Turner, E., Whitehouse, H., 2015. Seshat: The Global History Databank. Cliodynamics, 6(1): 77- 107.

35. Vodop'yanov, P., Sidorenko, I., 2019. The ambivalent nature of optimism in the context of the concept of new humanism. Humanities bulletin of Zaporizhzhe state engineering academy. 77. 13-22.

DOI: https://doi.org/10.30839/2072-7941.2019.177701

36. Voronkova, V., Metelenko, N., Nikitenko, V., Silina, I., 2019. System analysis of the economy of sustainable development as environmentally balanced and socially oriented one. Humanities Studies. 1 (78). 86-97.

DOI https://doi.org/10.26661/hst-2019-1-78-07

37. Voronkova, V., Kivliuk, O., Nikitenko, V., Oleksenko, R., 2018. "STEMeducation" as a factor in the development of "Smart-society" : forming of "STEMcompetence". Humanities bulletin of Zaporizhzhe state engineering academy. 72. 114-124.

\section{References}

1. Bell, D., 1973. The Coming of Post-Industrial Society. A Venture in Social Forecasting, NewYork: Basic Books.

2. Bell, D. , 1976. The Cultural Contradictions of Capitalism, NewYork: Basic Book.

3. Bojko, E., Voronkova, V., Nikitenko, V. , 2018. Methodology and organization of scientific researches in the field of social-humanitarian and behavioural sciences. Humanities bulletin of Zaporizhzhe state engineering academy. 72. 23-35.

4. Castells, M., 1996. The Rise of the Network Society, The Information Age: Economy, Society and Culture, Vol. I. (1996); Vol. II. (1997); Vol. III. (1998). Cambridge, MA; Oxford, UK.

Myths, pseudosciences, sciences \& arts in the XXI century noophilosophical analysis 
5. Ernst Ulrich von Weizsacker, Anders Wijkman, 2018. Come On! Capitalism, Shorttermism, Population and the Destruction of the Planet. A Report to the Club of Rome. Springer.

6. Gaudin, T., 1990. 2100 recit du prochain siecle. Paris, Editions Payot.

7. Huntington, S., 1996. The Clash of Civilizations and Remaking of World Order. Simon \& Schuster.

8. Inozemtsev, V.L., 2005. Book swallower. M. Ladomir.

9. Kirik, T. V., Shevchuk, I. K., Kirik, V. O., 2018. Competition of humanist paradigms during the reform of higher education in Ukraine. Humanities bulletin of Zaporizhzhe state engineering academy. 75. 119-131. DOI: https://doi.org/10.30839/2072-7941.2018.155558.

10. Korsak, K. V., 2011. Nooeconomics (4th wave) - the way of sustainable development of mankind in the XXI century. Economist. 1. 20-23.

11. Korsak, K. V., \& Korsak, Yu. K., 2019. Certificate of copyright registration for a literary written work of a scientific nature «Nooglossary-2 - Noosciences for the Future without Collapse» («Nooglossary-2»). №89780. 13.06.2019. K.: Ministry of Economic Development and Trade of Ukraine, Department of Intellectual Property.

12. Korsak, K. V., \& Korsak, Yu.K., 2017. Nooistoriya i noonauky pro mozhlyvist' druhoho ukrayins'koho odukhovlennya svitu [Noohistory and nooscience about the spiritualization of the world]. Humanitarnyy visnyk Zaporiz'koyi derzhavnoyi inzhenernoyi akademiyi: Zbirnyk naukovykh prats'., 69, 112-119 (URL: http://vestnikzgia.com.ua/article/view/102113) [in Ukrainian]

13. Korsak, K. V., \& Liashenko, L .N., 2017. Gipoteza fenomena proiskhozhdeniya i rasprostraneniya na planete indoyevropeyskoy sem'i yazykov [The hypothesis of the phenomenon of origin and distribution on the planet of the Indo-European family of languages]. RELGA. - RELGA, 3(321) (Url: http://www.relga.ru/Environ/WebObjects/tguwww.woa/wa/Main?textid=4921\&level1=main\&level2=articles)

14. Korsak, K. V., Korsak, Y .K., 2018. The only way to save humanity from total collapse - nootechnologies and noosciences. Humanities bulletin of Zaporizhzhe state engineering academy. 74. 24-38. DOI: https://doi.org/10.30839/2072-7941.2018.149632.

15. Kozlovets, M. A., Horokhova, L. V., Melnychuk, V. V. , 2019. Humanistic type of rationality as a factor of the formation of co-evolution-innovation strategy for sustainable development of mankind. Humanities bulletin of Zaporizhzhe state engineering academy. 77. 47-68. Doi: https://doi.org/10.30839/2072-7941.2019.177708.

16. Kyrychenko, M., 2018. Concept of simulacra of virtual-online culture of informational society: conceptual survey of postemodernists. Humanities bulletin of Zaporizhzhe state engineering academy. 73. 62-71.

17. Kyurchev, V., Oleksenko, R., 2019. Creative personality and its dignicular role in the formation of a known economy in the conditions of the challenges of globalization of informational society. Humanities bulletin of Zaporizhzhe state engineering academy. 76. 132-145.DOI: https://doi.org/10.30839/2072-7941.2019.165111.

18. Levcheniuk, Y., 2018. From human to posthuman. Humanities bulletin of Zaporizhzhe state engineering academy. 72. 62-70.

19. Melnik, V.,V. 2018. A new strategy of education as factor of sustainable development in the conditions of evolution from informational society to "Society knowledge". Humanities bulletin of Zaporizhzhe state engineering academy. 73. 146-156.

20. Melnyk, V. V., 2018. Sustainable development management concept in fourth wave of globalization (globalization 4.0). Humanities bulletin of Zaporizhzhe state engineering academy. 75. 180-192.DOI https://doi.org/10.30839/2072-7941.2018.155563.

21. Melnyk, V. V., 2018. Information management as a factor of innovative society development. Humanities bulletin of Zaporizhzhe state engineering academy. 74. 39-47. DOI: https://doi.org/10.30839/2072-7941.2018.149651.

(C) Korsak Kostiantyn, Korsak Yurii, Lyashenko Larysa, Pokhresnyk Anatolii 2019 
22. Melnyk, V., 2019. Formation of the developmental concept of informative-digital technologies in digital (electronic) conditions of the era. Humanities bulletin of Zaporizhzhe state engineering academy. 76. 200-209. DOI: https://doi.org/10.30839/20727941.2019.165135.

23. Nikitenko, V. O., 2018. Human interaction, culture and education as a key driver of sustainable development information. Humanities bulletin of Zaporizhzhe state engineering academy. 75. 79-89. DOI https://doi.org/10.30839/2072-7941.2018.155555.

24. Nikitenko, V. , 2018. Formation of "clip culture" and its impact on development and self-identification of personality in informational society. Humanities bulletin of Zaporizhzhe state engineering academy. 73. 105-113 a

25. Punchenko, O., Voronkova, V., Vodop'yanov, P., 2019. "New Enlichtenment": new fractality in transformation processes of education. Humanities bulletin of Zaporizhzhe state engineering academy. 77. 144-159. DOI: https://doi.org/10.30839/2072-7941.2019.177746.

26. Rakitov, A.I., 1991. The philosophy of the computer revolution. M. Politizdat.

27. Rizhova, I., Shmarina A. (2019). The impact of innovative technologies on a design of the spatial - object environment as a factor of gradual development. Humanities bulletin of Zaporizhzhe state engineering academy. 76. 90-102 DOI: https://doi.org/10.30839/20727941.2019.165097.

28. Sosnin A., 2019. New approaches to the analysis of information and communication activities in the conditions of modern globalization challenges. Humanities bulletin of Zaporizhzhe state engineering academy. 76. 169-183 DOI: https://doi.org/10.30839/20727941.2019.165126.

29. Sosnin, O. V., Kononets, M.O., 2019. Problem issues of education of youth information and communication sustainability in the conditions of the new psycho-computer reality. Humanities Studies. 1 (78). 62-74.DOI https://doi.org/10.26661/hst-2019-1-78-05.

30. Sydorenko S., 2019. Philosophy of digital technology development in the sphere of medicine in "globalization 4.0". Humanities bulletin of Zaporizhzhe state engineering academy. 76. 44-55 DOI: https://doi.org/10.30839/2072-7941.2019.165084.

31. Teslenko, T. V., 2018. «Spirit/mind-body» dihotomy and its impact on the formation of «homo creativus» in the context of economic philosophy: methodological bases. Humanities bulletin of Zaporizhzhe state engineering academy. 75. 53-64. DOI https://doi.org/10.30839/2072-7941.2018.155552.

32. Toffler, A., 1980. The Third Wave. New York: William Morrow.

33. Tovarnichenko, V., 2019. Pseudoscience and information security in smart-society. Humanities Studies. 1(78). 15-26. DOI https://doi.org/10.26661/hst-2019-1-78-01.

34. Turchin, P., Brennan, R., Currie, T., Feeney, K., François, P., Hoyer, D., Manning, J., Marciniak, A., Mullins, D., Palmisano, A., Peregrinej, P., Turner, E., Whitehouse, H. , 2015. Seshat: The Global History Databank. Cliodynamics, 6(1). 77- 107.

35. Vodop'yanov, P., Sidorenko, I., 2019. The ambivalent nature of optimism in the context of the concept of new humanism. Humanities bulletin of Zaporizhzhe state engineering academy. 77. 13-22. DOI: https://doi.org/10.30839/2072-7941.2019.177701.

36. Voronkova, V., Metelenko, N., Nikitenko, V., Silina, I. , 2019. System analysis of the economy of sustainable development as environmentally balanced and socially oriented one. Humanities Studies. 1 (78). 86-97.DOI https://doi.org/10.26661/hst-2019-1-78-07.

37. Voronkova, V., Kivliuk, O., Nikitenko, V., Oleksenko, R., 2018. "STEM-education" as a factor in the development of "Smart-society" : forming of "STEM-competence". Humanities bulletin of Zaporizhzhe state engineering academy. 72. 114-124.

КОРСАК, К. В. - доктор філософських наук, професор, кафедра іноземних мов та соціально-гуманітарних дисциплін, Київський медичний університет (Київ, Україна)

E-mail: kvkorsak@gmail.com, ORCID iD: https://orcid.org/0000-0001-7715-9720 
КОРСАК, Ю. К. - кандидат філософських наук, Інститут вищої освіти Національної академії педагогічних наук (Київ, Україна)

E-mail: olte@ukr.net, ORCID iD: https://orcid.org/0000-0003-3100-8630

ЛЯШЕНКО, Л. М. - кандидат педагогічних наук, доцент, кафедра іноземних мов для природничих факультетів, Київський національний університет імені Тараса Шевченка (Київ, Україна)

E-mail: larnik1881@gmail.com, ORCID iD: https://orcid.org/0000-0002-6860-8552

ПОХРЕСНИК, А. К. - кандидат філософських наук, доцент, директор Київського технікуму електронних приладів (Київ, Україна)

E-mail: ktep2006@ukr.net, ORCID iD: https://orcid.org/0000-0002-4637-7140

\section{МІФИ, ПСЕВДОНАУКИ, ТОЧНІ ТА ГУМАНІТАРНІ НАУКИ У ХХІ СТОЛІТТІ: НООФІЛОСОФСЬКИЙ АНАЛІЗ}

Анотація. Ното Sapiens Sapiens збільшив свою чисельність приблизно в 1 мільйон разів і завоював планету. Але він все ще знаходиться в небезпеці і може загинути, оскільки став головним руйнівним елементом біосфери. Це стало особливо очевидним разом зі спалахом глобальної пандемії CoViD-19. Наше дослідження детерміноване професійною етикою та бажанням запропонувати реальні засоби боротьби з пандемією та колапсами. Ми бачимо мету в критичному аналізі відомих прогнозів майбутнього. Конкретним завданням $\epsilon$ формулювання пропозиції реальних кроків на шляху поступової побудови бази для ноосфери. Використовуються методи класичних наукових досліджень, критичний, історичний, логічний та порівняльний аналізи. Вони доповнюються досягненнями ноотехнологій та тими відкриттями ноонаук, що необхідні для стратегічних прогнозів на великий інтервал часу. Ми використовуємо інфографіку для надання пояснень та пропозицій. Засвідчено звуженість інформаційної основи та хибність відомих апокаліптичних прогнозів майбутнього. Роз'яснено причини цього явища та відсутність реальних проектів ліквідації загрози нових пандемій і колапсів. Доведено факт перебування людства у черговій точці біфуркації. Запропоновано рухатися в ноомайбутнє через масове використання екологічно чистих ноотехнологій і ноопроцесів, які повинні повністю замінити індустріальні і смарттехнології. Доведено факт виникнення "ноохвилі" в еволюції людства, яка отримує імпульс зростання від поєднання гуманітарних та природничих наук з ноопроцесами. Усунення нових загроз пандемій і колапсів цілком можливе у випадку реалізації людством скоординованого плану ноопрогресу шляхом ефективного використання сонячної енергії та реплікаторів (3D-принтерів) високих поколінь, які працюють на природних матеріалах.

Ключові слова: криза людства, етапи еволюції, міфи, псевдонауки, науки i мистецтва, ноотехнології, ноонауки

КОРСАК, К. В. - доктор философских наук, профессор, кафедра иностранных языков и социально-гуманитарных дисциплин, Киевский медицинский университет (Киев, Украина)

E-mail: kvkorsak@gmail.com, ORCID iD: https://orcid.org/0000-0001-7715-9720

КОРСАК, Ю. К. - кандидат философских наук, Институт высшего образования Национальной академии педагогических наук (Киев, Украина)

E-mail: olte@ukr.net, ORCID iD: https://orcid.org/ 0000-0003-3100-8630

ЛЯШЕНКО, Л. Н. - кандидат педагогических наук, доцент, кафедра иностранных языков для естественных факультетов, Киевский национальный университет имени Тараса Шевченко (Киев, Украина)

E-mail: larnik1881@gmail.com, ORCID iD: https://orcid.org/0000-0002-6860-8552

ПОХРЕСНИК, А. К. - кандидат философских наук, доцент, директор Киевского техникума электронных приборов (Киев, Украина)

(C) Korsak Kostiantyn, Korsak Yurii, Lyashenko Larysa, Pokhresnyk Anatolii 2019 
E-mail: ktep2006@ukr.net, ORCID iD: https://orcid.org/0000-0002-4637-7140

\title{
МИФЫ, ПСЕВДОНАУКИ, ТОЧНЫЕ И ГУМАНИТАРНЫЕ НАУКИ В ХХІ ВЕКЕ: НООФИЛОСОФСКИЙ АНАЛИЗ
}

\begin{abstract}
Аннотация. Homo Sapiens Sapiens увеличил свою численность примерно в 1000 000 раз и завоевал планету. Но он все еще находится в опасности и может погибнуть, поскольку стал главным разрушительным элементом биосферы. Это стало особенно очевидным с развитием вспышки глобальной пандемии CoViD-19. Наше исследование детерминировано профессиональной этикой и желанием предложить реальные средства борьбы с пандемией и коллапсами. Мы видим цель в критическом анализе известных прогнозов будущего. Конкретной задачей является формулировка предложения реальных шагов на пути постепенного построения базы для ноосферы. Используются методы классических научных исследований, критический, исторический, логический и сравнительный анализы. Они дополняются достижениями ноотехнологий и теми открытиями ноонаук, которые необходимы для стратегических прогнозов на большой интервал времени. Мы используем инфографику для объяснений и предложений. Засвидетельствовано узость информационной основы и ошибочность известных апокалиптических прогнозов будущего. Разъяснено причины этого явления и отсутствие реальных проектов ликвидации угрозы новых пандемий и коллапсов. Доказан факт пребывания человечества в очередной точке бифуркации. Предложено двигаться в нообудущее по пути массового использования экологически чистых ноотехнологий и ноопроцессов, которые должны полностью заменить индустриальные и смарт-технологии. Доказан факт возникновения "нооволны" в эволюции человечества, получающей импульс роста от сочетания гуманитарных и естественных наук с ноопроцессами. Устранение новых угроз пандемий и коллапсов вполне возможно в случае реализации человечеством скоординированного плана ноопрогресса путем эффективного использования солнечной энергии и репликаторов (3D-принтеров) высоких поколений, работающих на природных материалах.
\end{abstract}

Ключевые слова: кризис человечества, этапы эволюции, мифы, псевдонауки, точные и гуманитарные науки, ноотехнологии, ноонауки 